\title{
Base-Flow Yields of Watersheds in the Berkeley County Area, West Virginia
}

By Ronald D. Evaldi and Katherine S. Paybins

Prepared in cooperation with the Berkeley County Commission

Data Series 216 


\section{U.S. Department of the Interior DIRK KEMPTHORNE, Secretary \\ U.S. Geological Survey \\ P. Patrick Leahy, Acting Director}

\section{U.S. Geological Survey, Reston, Virginia: 2006}

For product and ordering information:

World Wide Web: http://www.usgs.gov/pubprod

Telephone: 1-888-ASK-USGS

For more information on the USGS--the Federal source for science about the Earth, its natural and living resources, natural hazards, and the environment:

World Wide Web: http://www.usgs.gov

Telephone: 1-888-ASK-USGS

Any use of trade, product, or firm names is for descriptive purposes only and does not imply endorsement by the U.S. Government.

Although this report is in the public domain, permission must be secured from the individual copyright owners to reproduce any copyrighted materials contained within this report.

Suggested citation:

Evaldi, R.D., and Paybins, K.S., 2006, Base-flow yields of watersheds in the Berkeley County Area, West Virginia: U.S. Geological Survey Data Series 216, 4 p., 1 pl. 


\section{Contents}

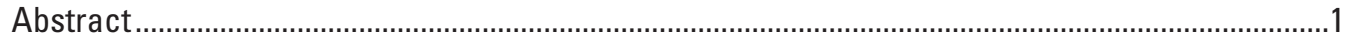

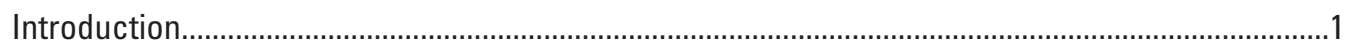

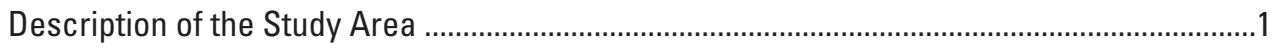

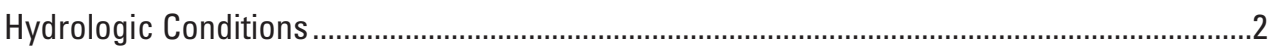

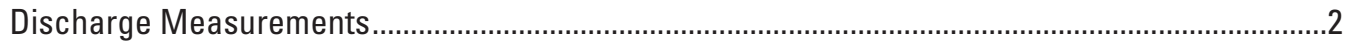

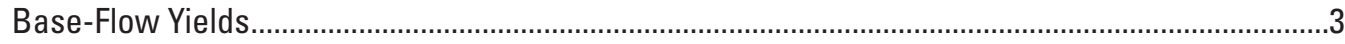

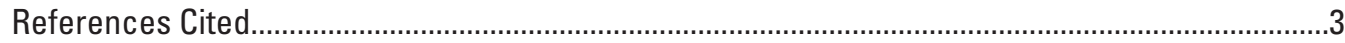

\section{Figure}

1. Map showing base-flow yields of watershed in the Berkeley County area,

West Virginia ....................................................................................................... separate file

\section{Table}

1. Discharge measurements of streams in the Berkeley County area,

West Virginia, July 25-28, 2005, and May 4, 2006.

\section{Conversion Factors and Datums}

\begin{tabular}{|c|c|c|}
\hline Multiply & By & To obtain \\
\hline \multicolumn{3}{|c|}{ Length } \\
\hline inch (in.) & 2.54 & centimeter $(\mathrm{cm})$ \\
\hline foot $(\mathrm{ft})$ & 0.3048 & meter $(\mathrm{m})$ \\
\hline mile (mi) & 1.609 & kilometer $(\mathrm{km})$ \\
\hline \multicolumn{3}{|c|}{ Area } \\
\hline acre & 0.4047 & square hectometer $\left(\mathrm{hm}^{2}\right)$ \\
\hline square mile $\left(\mathrm{mi}^{2}\right)$ & 259.0 & square hectometer $\left(\mathrm{hm}^{2}\right)$ \\
\hline \multicolumn{3}{|c|}{ Rate } \\
\hline inch per year (in/yr) & 2.54 & centimeter per year (cm/yr) \\
\hline cubic foot per second $\left(\mathrm{ft}^{3} / \mathrm{s}\right)$ & 0.02832 & cubic meter per second $\left(\mathrm{m}^{3} / \mathrm{s}\right)$ \\
\hline gallon per minute (gal/min) & 0.06309 & liter per second $(\mathrm{L} / \mathrm{s})$ \\
\hline gallon per day (gal/d) & 0.003785 & cubic meter per day $\left(\mathrm{m}^{3} / \mathrm{d}\right)$ \\
\hline $\begin{array}{l}\text { gallon per day per acre } \\
{[(\mathrm{gal} / \mathrm{d}) / \mathrm{acre}]}\end{array}$ & 0.000935 & $\begin{array}{l}\text { cubic meter per day per square } \\
\text { hectometer }\left[\left(\mathrm{m}^{3} / \mathrm{d}\right) / \mathrm{hm}^{2}\right]\end{array}$ \\
\hline
\end{tabular}

Temperature in degrees Fahrenheit $\left({ }^{\circ} \mathrm{F}\right)$ may be converted to degrees Celsius $\left({ }^{\circ} \mathrm{C}\right)$ as follows:

${ }^{\circ} \mathrm{C}=\left({ }^{\circ} \mathrm{F}-32\right) / 1.8$

Horizontal coordinate information is referenced to the North American Datum of 1983 (NAD 83).

Vertical control information is referenced to the National Geodetic Vertical Datum of 1929

(NGVD 29). Altitude, as used in this report, refers to distance above the vertical datum. 


\title{
Base-Flow Yields of Watersheds in the Berkeley County Area, West Virginia
}

\author{
By Ronald D. Evaldi and Katherine S. Paybins
}

\section{Abstract}

Base-flow yields at approximately 50 percent of the annual mean ground-water recharge rate were estimated for watersheds in the Berkeley County area, W.Va. These baseflow yields were determined from two sets of discharge measurements made July 25-28, 2005, and May 4, 2006. Two sections of channel along Opequon Creek had net flow losses that are expressed as negative base-flow watershed yields; these and other base-flow watershed yields in the eastern half of the study area ranged from -940 to 2,280 gallons per day per acre ((gal/d)/acre) and averaged 395 (gal/d)/acre. The base-flow yields for watersheds in the western half of the study area ranged from 275 to 482 (gal/d)/acre and averaged $376(\mathrm{gal} / \mathrm{d}) / \mathrm{acre}$.

\section{Introduction}

Berkeley County, W.Va., is in the Eastern Panhandle of the State, about 65 mi northwest of Washington, D.C. The 2004 population of Berkeley County was 89,400 and had increased about 50 percent since 1990 (U.S. Census Bureau, 2006). The primary source of water for most domestic and community water-supply systems in Berkeley County is ground water (Shultz and others, 1995). State and local officials are concerned about the effects that the escalating demands for water are having on the ground-water resources of the county. Should long-term use of ground water exceed its rate of replenishment, water shortages could result. Estimates of ground-water-recharge rates throughout the county are needed for resource management planning. Ground-water recharge is a function of precipitation, temperature, runoff, infiltration rates, geology, topography, and vegetative cover. These factors are difficult to quantify by direct measurement and, as a surrogate, ground-water recharge can be estimated from stream-discharge data obtained during base-flow conditions. The base flow of streams is derived from ground-water outflow and, except for possible outflow differences caused by interbasin water transfers, the relative rates of base-flow yields from watersheds are assumed to be proportional to recharge.
Discharges of streams and a wastewater-treatment-plant outfall in the Opequon Creek Watershed in Berkeley County were measured during base-flow conditions in July 25-28, 2005 (Evaldi and Paybins, 2006). In order to extend the study area to describe the base flow of streams throughout the county, additional stream-discharge measurements were made during base-flow conditions on May 4, 2006. These included stream-discharge measurements in the Opequon Creek Watershed, in the Back Creek Watershed, and on small tributary streams that drain directly to the Potomac River (table 1, at back of report; fig. 1). Presentation of these measurements herein is the result of a cooperative effort by the U.S. Geological Survey (USGS) and the Berkeley County Commission.

\section{Description of the Study Area}

Berkeley County, which encompasses a land area of $325 \mathrm{mi}^{2}$, is bounded by Jefferson County, W.Va., to the east; Morgan County, W.Va., to the west; the State of Virginia to the south; and the Potomac River to the north (fig. 1). As reported by Shultz and others (1995), the eastern half of Berkeley County is characterized by gently rolling topography, with altitudes ranging from about 310 to $800 \mathrm{ft}$. The western half of the county is characterized by northeastward-trending parallel ridges and valleys, with altitudes ranging from about 310 to $2,200 \mathrm{ft}$.

The Potomac River drains all of Berkeley County. The principal tributaries to the Potomac River are Meadow Branch, Cherry Run, Back Creek, Harlan Run, Opequon Creek, and Rockymarsh Run. Four tributaries of Opequon Creek are of significant size: Tuscarora Creek, Evans Run, Middle Creek, and Mill Creek. The base-flow discharges of all of these streams were measured, except for that of Meadow Branch (which flows through the Sleepy Creek Public Hunting and Fishing Area). Some tributaries to Opequon Creek that are entirely within Jefferson County are shown in this report because their flow contributions were used in the base-flow yield calculations for Berkeley County watersheds. 


\section{Hydrologic Conditions}

This study is based on stream discharge measurements obtained during similar base-flow conditions during July 25-28, 2005, and on May 4, 2006. During these periods, the base-flow discharge provided by ground-water outflow to streams in the study area was approximately half of the longterm mean annual ground-water recharge rate estimated by Kozar and Mathes (2001).

Streamflow at USGS gaging station 01616500 Opequon Creek near Martinsburg, W.Va. (site 37, table 1, fig. 1), averaged $106 \mathrm{ft}^{3} / \mathrm{s}$ (47,600 gal/min) during July 25-28, 2005 a value that is approximately equivalent to the 40 -percent duration (flow equaled or exceeded 40 percent of the time) of summer flows reported by Wiley (2006). The station recorded a hydrograph rise to $210 \mathrm{ft}^{3} / \mathrm{s}(94,300 \mathrm{gal} / \mathrm{min})$ on July 22; however, this rise in flow is believed to reflect runoff from that part of the 273- $\mathrm{mi}^{2}$ drainage area that is upstream from the study area because rainfall totaled only 0.02 in. during July 16-24 at Martinsburg (National Climatic Data Center, 2005). Therefore, streamflows measured July 25-28, 2005, were assumed to be derived from base flow rather than from surface runoff. Although 0.12 in. of rain fell in Martinsburg on July 25 and 0.13 in. fell on July 27, most of this precipitation was believed to have been evapotranspired as a result of high temperatures (62 to $\left.97^{\circ} \mathrm{F}\right)$ during July $25-28$ in the Martinsburg area (National Climatic Data Center, 2005).

Streamflow at USGS gaging station 01616500 Opequon Creek near Martinsburg averaged $100 \mathrm{ft}^{3} / \mathrm{s}(44,900 \mathrm{gal} / \mathrm{min})$ on May 4, 2006, a value that is approximately equivalent to the 45-percent duration of summer flows reported by Wiley (2006). Streamflow at USGS gaging station 01614000 Back Creek near Jones Springs (site 5; table 1, fig. 1) averaged 71 $\mathrm{ft}^{3} / \mathrm{s}(31,900 \mathrm{gal} / \mathrm{min})$ on May 4, 2006, a value approximately equivalent to the 70-percent duration of summer flows.

Streams were considered at base flow on May 4, 2006, because no measurable rainfall was reported at Martinsburg during April 26 through May 4, 2006 (National Climatic Data Center, 2006).

It was not possible to define all of the hydrologic factors affecting the results of this study. Pumps were noted as running July 25-28, 2005, at Kilmer Spring and at Lefevre Spring, but outflow measurements were not adjusted because the amount of diversion was unknown (Evaldi and Paybins, 2006). Other unknown diversions or interbasin transfers of water could have occurred during the study.

\section{Discharge Measurements}

Discharge information was obtained during July 25-28, 2005, at 69 stream sites, 31 springs, and 1 wastewater-treatment-plant outfall in the Opequon Creek Watershed (Evaldi and Paybins, 2006). The wastewater-treatment-plant outfall measurement and 17 of the stream measurements were used in this study. Discharge measurements were made at 32 additional stream sites on May 4, 2006.

All sites during both time periods were measured by wading with current meters. Observations of width, depth, and velocity were made at intervals in a cross section of the stream or outflow. Measured discharge is the summation of the products of the subsection areas of the cross sections and their respective average velocities (Rantz and others, 1982). Equipment used for measuring flow was checked for accuracy before and after data collection and was within acceptable operational limits. The accuracy of individual discharge measurements was dependent on channel or outflow conditions, and error generally was estimated to be less than 10 percent.

A means of adjusting the measurements to similar conditions was employed because the stream-discharge measurements were obtained during slightly different flow conditions. The measurement adjustments were based on comparison of streamflow-gaging-station records for the dates of the Berkeley County discharge measurements to a flow statistic estimated from the long-term gaging-station records. The flow statistic chosen as the basis for the adjustments was the mean ground-water recharge rate estimates for USGS gaging stations 01616500 Opequon Creek near Martinsburg (9.8 in/yr) and 0161700 Back Creek near Jones Springs ( 8.5 in/yr) (Kozar and Mathes, 2001). These ground-water recharge rates can be expressed as mean watershed outflow rates, which for Opequon Creek near Martinsburg is $197 \mathrm{ft}^{3} / \mathrm{s}$ and for Back Creek near Jones Springs is $147 \mathrm{ft}^{3} / \mathrm{s}$.

The measurement adjustment factor used for Opequon Creek and other streams in the eastern half of the study area (sites 9-40, and 42-50) was the ratio of 50 percent of the longterm mean watershed outflow rate $\left(98.5 \mathrm{ft}^{3} / \mathrm{s}\right)$ to the flow of Opequon Creek near Martinsburg at the time of data collection. The flow of Opequon Creek near Martinsburg averaged $106 \mathrm{ft}^{3} / \mathrm{s}$ July 25-28, 2005, and $100 \mathrm{ft}^{3} / \mathrm{s}$ on May 4, 2006. Discharge measurements of streams in the eastern half of the study area during July 25-28, 2005, were adjusted by a factor of 0.929, and measurements on May 4, 2006, were adjusted by a factor of 0.985 . The measurement adjustment factor used for Back Creek and other streams in the western half of study area (sites 1-8) was the ratio of 50 percent of the long-term mean watershed outflow rate $\left(73.5 \mathrm{ft}^{3} / \mathrm{s}\right)$ to the flow of Back Creek near Jones Springs at the time of data collection. The flow of Back Creek near Jones Springs averaged $71 \mathrm{ft}^{3} / \mathrm{s}$ on May 4, 2006. Stream discharge measurements of Back Creek and other streams in the western half of the study area for May 4, 2006, were adjusted by a factor of 1.035 . 


\section{Base-Flow Yields}

Base-flow yields equivalent to approximately 50 percent of the annual mean ground-water recharge rate were estimated for watersheds in Berkeley County (table 1, fig. 1). For headwater-channel sites, the base-flow yields were computed as the measured outflow divided by the watershed drainage area. Base-flow yields for other stream-channel sections were computed as the change in channel discharge between measurement sites divided by the amount of intervening drainage area between them. The base-flow yields were expressed in gallons per day per acre (gal/d)/acre) of intervening drainage area. For computation of change in discharge between measurement sites along a channel, all tributary inflows to the channel reach and known wastewater-treatment-plant discharges were subtracted. Flow losses of -332 and -940 (gal/d)/acre were thus determined for two subwatersheds along Opequon Creek (sites 15 and 37, respectively). These negative watershed yields might indicate flow losses to the ground-water system, channel underflow, or possible discharge-measurement errors. The base-flow yield of watersheds in the eastern half of the study area, based on measurement sites 9-50, ranged from -940 to 2,280 (gal/d)/acre and averaged $395(\mathrm{gal} / \mathrm{d}) / \mathrm{acre}$. The base-flow yield of watersheds in the western half of the study area, based on measurement sites 1-8, ranged from 275 to 482 (gal/d)/acre and averaged 376 (gal/d)/acre.

\section{References Cited}

Evaldi, R.D., and Paybins, K.S., 2006, Channel gains and losses in the Opequon Creek Watershed of West Virginia, July 25-28, 2005: U.S. Geological Survey Data Series 179, $7 \mathrm{p}$.

Kozar, M.D., and Mathes, M.V., 2001, Aquifer-characteristics data for West Virginia: U.S. Geological Survey WaterResources Investigations Report 01-4036, 74 p.

National Climatic Data Center, 2005, Unedited local climatological data, accessed January 17, 2006, at http://cdo.ncdc. noaa.gov/ulcd/ULCD

National Climatic Data Center, 2006, Unedited local climatological data, accessed July 20, 2006, at http://cdo.ncdc. hoaa.gov/ulcd/ULCD

Rantz, S.E., and others, 1982, Measurement and computation of streamflow-Volume 1, Measurement of stage and discharge: U.S. Geological Survey Water-Supply Paper 2175, p. 79-183.
Shultz, R.A., Hobba, W.A., and Kozar, M.D., 1995, Geohydrology, ground-water availability, and ground-water quality of Berkeley County, West Virginia, with emphasis on the carbonate rock area: U.S. Geological Survey WaterResources Investigations Report 93-4073, 88 p.

U.S. Census Bureau, 2006, State \& county QuickFacts, accessed January 13, 2006, at http://quickfacts.census. gov/qfd/states

Wiley, J.B., 2006, Low-flow analysis and selected flow statistics representative of 1930-2002 for streamflow-gaging stations in or near West Virginia: U.S. Geological Survey Scientific Investigations Report 2006-5002, 190 p. 
Table 1. Discharge measurements of streams in the Berkeley County area, West Virginia, July 25-28, 2005, and May 4, 2006.

[---; unknown; ft 3 s, cubic feet per second; gal/d, gallon per day. Horizontal coordinates are referenced to North American Datum of 1983 (NAD 83)]

\begin{tabular}{|c|c|c|c|c|c|c|c|c|c|}
\hline \multirow{2}{*}{$\begin{array}{c}\text { Site } \\
\text { num- } \\
\text { ber }\end{array}$} & \multirow{2}{*}{ Date } & \multirow{2}{*}{ Latitude } & \multirow{2}{*}{ Longitude } & \multirow{2}{*}{$\begin{array}{l}\text { Drainage } \\
\text { area } \\
\text { (acres) }\end{array}$} & \multicolumn{2}{|c|}{ Discharge } & \multirow{2}{*}{$\begin{array}{c}\text { 'Adjusted } \\
\text { discharge } \\
\text { (gal/d) }\end{array}$} & \multirow{2}{*}{$\begin{array}{c}\text { 2Base- } \\
\text { flow } \\
\text { yield } \\
\text { [(gal/d)/ } \\
\text { acre] }\end{array}$} & \multirow{2}{*}{$\begin{array}{l}\text { Site name (in West Virginia } \\
\text { unless otherwise noted) }\end{array}$} \\
\hline & & & & & $\mathrm{ft}^{3} / \mathrm{s}$ & gal/d & & & \\
\hline 1 & $5 / 4 / 06$ & 393714.0 & 780142.0 & 5,570 & 2.82 & $1,823,000$ & $1,886,000$ & 339 & Cherry Run near Cherry Run \\
\hline 2 & $5 / 4 / 06$ & 392124.0 & 781116.0 & 110,000 & 47.7 & $30,830,000$ & $31,910,000$ & --- & Back Creek near DeHaven, Va. \\
\hline 3 & $5 / 4 / 06$ & 392608.0 & 780703.0 & 131,000 & 59.6 & $38,520,000$ & $39,870,000$ & 375 & Back Creek near Shanghai \\
\hline 6 & $5 / 4 / 06$ & 393522.0 & 780014.0 & 12,800 & 7.22 & $4,666,000$ & $4,830,000$ & 376 & Tilhance Creek near Johnsontown \\
\hline 7 & $5 / 4 / 06$ & 393536.0 & 780025.0 & 172,000 & 84.8 & $54,810,000$ & $56,730,000$ & 468 & Back Creek near Johnsontown \\
\hline 8 & $5 / 4 / 06$ & 393507.3 & 775713.1 & 10,500 & 4.61 & $2,980,000$ & $2,935,000$ & 280 & Harlan Run at Little Georgetown \\
\hline 9 & $5 / 4 / 06$ & 393542.2 & 775555.4 & 936 & 0 & 0 & 0 & 0 & Unnamed tributary near Prospect Hill \\
\hline 10 & $5 / 4 / 06$ & 393632.6 & 775216.1 & --- & 0 & 0 & 0 & 0 & Unnamed tributary near Marlowe \\
\hline 11 & $5 / 4 / 06$ & 393547.9 & 775207.9 & 703 & 0.103 & 66,570 & 65,570 & 93 & Jordan Run near Marlowe \\
\hline 16 & $5 / 4 / 06$ & 391725.7 & 780115.1 & 1,330 & 0.167 & 107,900 & 106,300 & 80 & Silver Spring Run near Ridgeway \\
\hline 17 & $5 / 4 / 06$ & 391808.7 & 780212.5 & 1,730 & 0.122 & 78,850 & 77,670 & 45 & Specks Run near Ridgeway \\
\hline 18 & $7 / 25 / 05$ & 391808.2 & 775924.7 & 3,960 & 2.71 & $1,752,000$ & $1,627,000$ & 411 & Turkey Run at Middleway \\
\hline 19 & $7 / 25 / 05$ & 391830.7 & 780010.0 & 10,200 & 3.82 & $2,469,000$ & $2,294,000$ & 107 & Turkey Run near mouth near Middleway \\
\hline 20 & $7 / 26 / 05$ & 392018.7 & 780326.4 & 10,200 & 3.49 & $2,256,000$ & $2,095,000$ & 205 & Mill Creek at Bunker Hill \\
\hline 21 & $7 / 26 / 05$ & 392000.3 & 780325.5 & 2,200 & 0.688 & 444,700 & 413,100 & 188 & Torytown Run at Bunker Hill \\
\hline 22 & $7 / 26 / 05$ & 391946.8 & 780225.9 & 14,100 & 7.90 & $5,106,000$ & $4,743,000$ & 1,360 & Mill Creek below Bunker Hill \\
\hline 23 & $7 / 26 / 05$ & 391854.3 & 780057.7 & 19,700 & 14.0 & $9,048,000$ & $8,406,000$ & 651 & Mill Creek near mouth near Middleway \\
\hline 24 & $5 / 4 / 06$ & 391840.8 & 775949.0 & 130,000 & 77.1 & $49,830,000$ & $49,080,000$ & 2,280 & Opequon Creek near Middleway \\
\hline 25 & $5 / 4 / 06$ & 392114.9 & 775759.2 & 136,000 & 93.1 & $60,170,000$ & $59,270,000$ & 1,660 & Opequon Creek near Egypt \\
\hline 26 & $7 / 26 / 05$ & 392234.0 & 780227.3 & 6,200 & 2.57 & $1,661,000$ & $1,543,000$ & 249 & Middle Creek near Darkesville \\
\hline 27 & $7 / 26 / 05$ & 392123.1 & 775813.8 & 9,440 & 4.92 & $3,180,000$ & $2,954,000$ & 435 & Middle Creek near mouth near Egypt \\
\hline 36 & $5 / 4 / 06$ & 392445.5 & 775644.2 & 3,230 & 0.168 & 108,600 & 107,000 & 33 & Cold Spring Run near Douglas Grove \\
\hline 37 & $5 / 4 / 06$ & 392527.2 & 775616.1 & 172,000 & 100 & $64,630,000$ & $63,660,000$ & -940 & Opequon Creek near Martinsburg \\
\hline 38 & $7 / 27 / 05$ & 392528.8 & 775629.3 & 4,560 & 2.94 & $1,900,000$ & $1,765,000$ & 378 & Evans Run near mouth near Martinsburg \\
\hline 39 & $5 / 4 / 06$ & 392639.0 & 775546.3 & 426 & 0.044 & 28,440 & 28,010 & 66 & Unnamed tributary near Van Clevesville \\
\hline 40 & $7 / 27 / 05$ & 392801.9 & 775808.2 & 7,590 & 4.84 & $3,128,000$ & $2,906,000$ & 383 & Tuscarora Creek at Martinsburg \\
\hline 41 & $7 / 27 / 05$ & 392706.1 & 775713.6 & -- & 3.94 & $2,546,000$ & $2,546,000$ & --- & Wastewater-treatment-plant outfall \\
\hline 42 & $7 / 27 / 05$ & 392654.8 & 775607.7 & 16,900 & 17.0 & $10,990,000$ & $10,210,000$ & 509 & Tuscarora Creek near mouth near Blairton \\
\hline 43 & $5 / 4 / 06$ & 392655.3 & 775526.4 & 1,860 & 0.809 & 522,900 & 515,000 & 277 & Unnamed tributary near Blairton \\
\hline 44 & $5 / 4 / 06$ & 392735.8 & 775509.9 & 198,000 & 121 & $78,200,000$ & $77,030,000$ & 372 & Opequon Creek near Files Crossroad \\
\hline 45 & $5 / 4 / 06$ & 392748.4 & 775507.2 & 3,660 & 0.306 & 197,800 & 194,800 & 53 & Unnamed tributary near Files Crossroad \\
\hline 46 & $5 / 4 / 06$ & 392757.4 & 775506.1 & 901 & 0.414 & 267,600 & 263,600 & 293 & Eagle Run near Files Crossroad \\
\hline 47 & $5 / 4 / 06$ & 392925.6 & 775442.3 & 742 & 0.335 & 216,500 & 213,300 & 287 & Unnamed tributary near Berkeley \\
\hline 48 & $5 / 4 / 06$ & 393101.4 & 775325.4 & 207,000 & 126 & $81,440,000$ & $80,210,000$ & 572 & Opequon Creek near Bedington \\
\hline 48 & $7 / 28 / 05$ & 393115.1 & 775324.2 & 7,340 & 9.37 & $6,056,000$ & $5,626,000$ & 767 & Hoke Run near mouth near Bedington \\
\hline 50 & $5 / 4 / 06$ & 392913.9 & 774942.2 & 10,300 & 5.88 & $3,800,000$ & $3,743,000$ & 363 & Rockymarsh Run near Scrabble \\
\hline
\end{tabular}

${ }^{1}$ Discharge measurements were adjusted to approximate outflow conditions at 50 percent of the long-term annual mean ground-water recharge rate. Discharge measurements of streams in the eastern half of the study area (sites 9-40, and 42-50) during July 25-28, 2005, were adjusted by a factor of 0.929 , and measurements on May 4, 2006, were adjusted by a factor of 0.985 . Discharge measurements of streams in the western half of the study area (sites 1-8) made on May 4, 2006, were adjusted by a factor of 1.035 .

${ }^{2}$ Base-flow yields are computed as the change in channel discharge between measurement sites divided by the change in drainage area between the sites. Yields are negative for losing (influent) reaches and positive for gaining (effluent) reaches. See figure 1 for areas associated with the base-flow yield calculations for the indicated measurement sites. 